\title{
MARKET REACTION OF STATE-OWNED PHARMACEUTICAL COMPANIES ON THE INDONESIA STOCK EXCHANGE TO NEWS REGARDING COVID-19 VACCINATION
}

\author{
Kusuma Putu Sri Arta Jaya \\ Universitas Pendidikan Nasional, Indonesia \\ E-mail: sriarta@undiknas.ac.id
}

\begin{abstract}
For almost 2 years, the world community has been hit by fear and crisis both in the health and economic fields due to the COVID-19 pandemic. The government's intensive health protocol campaign with the $3 \mathrm{M}$ jargon, namely wearing masks, maintaining distance and washing hands has not been able to stop the pandemic. To truly end the pandemic, it is necessary to create herd immunity. It is said that there are two ways to achieve herd immunity, namely by as many people as possible infected with the virus or by vaccination. Many studies have examined the market reaction to the COVID-19 pandemic, but very few studies have examined the market reaction to the development of a COVID-19 vaccine or the market reaction after the vaccination program started. This study examines whether there is a market reaction after the news regarding vaccinations in state-owned pharmaceutical companies on the Indonesia Stock Exchange. The test used in this study is the one sample ttest. The results of this study found (1) There was a positive market reaction in BUMN pharmaceutical companies to the arrival of vaccine raw materials for phase III clinical trials on July 19, 2020, (2) There was no positive market reaction in BUMN pharmaceutical companies to the events of Phase III vaccine clinical trials. para 11 August 2020 (3) There is no significant market reaction in state-owned pharmaceutical companies after the arrival of the first phase vaccine in Indonesia on 6 December 2020 (4) There is no positive market reaction in state-owned pharmaceutical companies to the administration of the first vaccine in Indonesia on 13 January 2021.
\end{abstract}

\section{KEY WORDS}

Vaccines, COVID-19, abnormal returns.

The COVID-19 pandemic has been going on for almost two years. For almost 2 years, the world community has been hit by fear and crisis, both in the health and economic fields. Many sectors have been affected by the COVID-19 pandemic, such as tourism where it is difficult for people to travel due to the outbreak, education which requires face-to-face learning, and even restrictions on social, transportation, worship and cultural restrictions. After being declared a pandemic by the World Health Organization (WHO), financial markets began to decline significantly around the world. In fact, infectious diseases, such as influenza, SARS, Ebola virus, and COVID-19, often threaten the health and safety of individuals (Guo and Cao, 2020). Out of fear, traders started selling stocks, and investors feared themselves from buying stocks and the Shanghai Stock Exchange, Tokyo Stock Exchange, New York Stock Exchange, Nasdaq all started to bleed (Chowdhury and Dihar, 2021).

Real knowledge and action from the government and the community regarding PHBS will always be able to reduce the number of COVID-19 cases, so that the COVID-19 pandemic period can end quickly (Yanti, et al., 2020). Therefore, the government has intensively carried out health protocol campaigns with the $3 \mathrm{M}$ jargon, namely wearing masks, maintaining distance and washing hands. However, to truly end the pandemic, it is necessary to create herd immunity. It is said that there are two ways to achieve herd immunity, namely by as many people as possible infected with the virus or by vaccination. Vaccination is one of the most powerful medical interventions in global health (Radice et al, 2019). Fulfillment of the Covid-19 vaccine is the full responsibility of the government as a form of realizing the 
goals of the State as we can see in the fourth paragraph of the Preamble to the 1945 Constitution of the Republic of Indonesia, namely protecting the entire Indonesian nation and the entire homeland of Indonesia, advancing public welfare, educating the nation's life, and participating in implementing world order based on independence, eternal peace and social justice (Masnun, et al. 2021). Safe and effective prophylactic vaccines are urgently needed to tackle a pandemic, which has devastating medical, economic and social consequences (Polack et al., 2021).

Countries in ASEAN or the world, including Indonesia, are faced with two risk assumptions. The risk of economic pressure due to Covid-19 will decrease if a vaccine is found immediately (upside risk), while the risk of economic pressure will deepen if the number of Covid-19 cases continues to increase in the second quarter of 2020 (downside risk) (Muhyiddin, 2020). In mid-2020, in July, there was good news that was expected to end the COVID-19 pandemic, namely the receipt of raw materials for clinical trials of vaccines imported from China. President Jokowi also appointed two state-owned pharmaceutical companies (BUMN) Indofarma and Kimia Farma to process raw materials and distribute vaccines to be imported from China's Sinovac company.

The first choice of vaccine used by the Indonesian government was made by the Chinese company Sinovac. In addition, many vaccines have been discovered by other countries, including from Pfizer, Aztra Zeneca, Johnson \& Johnson, Moderna. In addition to Sinovac, the Indonesian government also uses the Astra Zeneca and Moderna vaccines. The COVID-19 pandemic has caused the International Monetary Agency (IMF) to predict a global economic slowdown (Saraswati, 2020). So this vaccine news can be a booster to accelerate economic recovery. The influence of non-economic external events cannot be separated from the activities of the capital market, although it is not directly tied to the dynamics that occur in the capital market (Agustiawan and Sujana, 2020).

Many studies have examined the market reaction to the COVID-19 pandemic, but very few studies have examined the market reaction to the development of a COVID-19 vaccine or the market reaction after the vaccination program started. Sambuari, et al. (2020) examines the market reaction of food and beverage companies on the Indonesia Stock Exchange to the corona virus event, there is a market panic towards trading activity after the event, so that there are differences in the frequency before and after the event in terms of trading transactions. Welley, et al. (2020) found that there was a significant difference in the stock prices of Kimia Farma and Indofarma before and after the announcement of vaccine development. Research shows that in the last 50 years, vaccination has saved more lives in the world than other health products and procedures that make vaccines "the miracle of modern medicine" (Anderson in Gadelha et al., 2020). Therefore, the development of a vaccine absolutely must be carried out considering that the pandemic has been going on for quite a long time and the victims have been very large. The development of vaccines and the establishment of global immunization strategies against diseases with high transmission rates have determined the radical changes in diseases that affect humankind (Gadelha et al., 2020). The immunogen market is always dynamic as countries introduce new vaccines and change preferences for many older vaccines (Ling, 2020).

$\mathrm{H} 1$ : There is a positive market reaction in state-owned pharmaceutical companies in Indonesia to the arrival of vaccine raw materials from Sinovac for the purposes of Phase III clinical trials.

COVID-19, thousands of people die every day, but there is light at the end of this dark tunnel since vaccines for the new virus have been rapidly developed over the past year and various drugs are now being administered (Vierlboeck and Nilchiani, 2021). Another effort that has so far been carried out to control the spread of Covid-19 is through research to produce a vaccine. Various countries are competing to be able to produce vaccines, because apart from dealing with the pandemic, vaccines will become a commodity that will be sought after and have high economic value (Masnun, et al., 2021). The clinical trial conducted by the state-owned company Biofarma on August 11, 2020 gave a breath of fresh air, especially since the Phase III clinical trial was declared successful. With this result the vaccine is ready for mass production and distribution. 
H2: There is a positive market reaction in state-owned pharmaceutical companies in Indonesia to the final stage vaccine clinical trial.

Vaccine development is a hope during the pandemic to become a "game-changer" for the recovery of social and economic conditions (Hartono, 2021). The vaccine that has been successfully developed by the Chinese company Sinovac will land in Indonesia and will soon be ready for injection. Although the research has been in a fairly short period of time since the beginning of the pandemic, news like this will be an additional boost for the economic recovery. Some countries are ready to grant emergency use permits or conditional approvals for public health reasons (Hartono 2021). With the arrival of the vaccine, it is hoped that the market will again respond positively to this news, especially for state-owned pharmaceutical companies. Vaccines can provide highly cost-effective technologies to treat infectious diseases, save lives and prevent the potential for millions of dollars in health expenditures (Danzon and Pereira, 2011). Rossman et al (2021) found that a greater and earlier reduction in COVID-19 cases and hospitalizations was observed in individuals older than 60 years, followed by younger age groups, in order of priority for vaccination in Israel. The arrival of the vaccine is actually very positive news because it is no longer a clinical trial but is already a vaccine that will be injected directly en masse.

$\mathrm{H} 3$ : There is a positive market reaction for state-owned pharmaceutical companies in Indonesia to the arrival of the first vaccine in Indonesia.

The vaccination program will start running on January 13,2021 , with a target of more than 200 million Indonesians. President Jokowi took part in the vaccine injection as one of the first to receive the vaccine. This news is certainly positive news for the market in general and state-owned pharmaceutical companies in particular. Sinovac vaccines can be stored in a standard refrigerator at $2-80^{\circ} \mathrm{C}$. The vaccine has undergone a three-phase trial and is considered $91.25 \%$ effective in Turkey and 65.3\% effective in Indonesia (Halim, 2021).

Vaccines clearly make individuals less susceptible to infectious diseases and also reduce the chances of unvaccinated people getting the disease (Demirci and Erkip, 2019). To achieve herd immunity, it takes more than $70 \%$ of the population to get the vaccine. The first vaccine injection in Indonesia on January 13, 2021 is expected to be the beginning of the process of stopping the pandemic and bringing activities back to normal. The findings of Prado et al (2021) show the increasing demand for vaccines is increasing, not only for population growth and previous demand, but also for the pressures that have been exerted recently due to the COVID-19 pandemic. Finally, what has been awaited has actually been realized and the hope that the pandemic will end soon is in sight.

$\mathrm{H} 4$ : There is a positive market reaction for pharmaceutical companies in Indonesia to the first stage of vaccination.

\section{METHODS OF RESEARCH}

The form of this research is a comparative analysis in which the researcher tries to test abnormal stock returns in state-owned pharmaceutical companies in every important event related to vaccination during the COVID-19 pandemic. This study uses secondary data in the form of daily stock closing prices which are accessed through www.finance.yahoo.com. Abnormal returns around the event date are used as a measure of market reaction and tested by the one sample t-test method using the SPSS for windows application. The use of one sample t-test is used to test whether the abnormal return of the stock after the event is different from zero. The dates used in this study are 19 July 2020, 11 August 2020, 6 December 2020, 13 January 2021. This study takes the observation period from 0 to 10 days after the event date. The sample in this study is a state-owned pharmaceutical company listed on the Indonesia Stock Exchange, namely Kimia Farma, Indofarma \& Phapros.

Abnormal returns in this study were measured using the market model method with:

(1) Actual return (Hartono, 2010:207):

$$
R_{i, t}=\frac{P_{i, t}-P_{i, t-1}}{P_{i, t-1}}+\text { Yield }
$$


Where: $R_{i, t}=$ Return actually occurs to $\mathrm{i}$ security in period $\mathrm{t} ; P_{i, t}=$ Current relative stock price; $P_{i, t-1}=$ Previous stock price.

(2) Expected return using the market model method (Hartono, 2009:563):

$$
R_{i . j}=\alpha_{i}+\beta_{i} \cdot R_{M j}+\varepsilon_{i / j}
$$

Where: $R_{i . j}=$ Expected return of the $\mathrm{i}$ security in the $\mathrm{j}$ estimation period; $\alpha_{i}=$ Intercept for security I; $\beta_{i}$ = Slope coefficient which is Beta of the i security; $R_{M j}=$ Market index return in the $\mathrm{j}$ estimation period which can be calculated by the formula $=(\mathrm{CSPI}-\mathrm{JCl}-1) / \mathrm{JCl}-1 ; \varepsilon_{i . j}=$ Error of the i security residual in the jestimation period.

(3) Abnormal returns (Hartono, 2009:558):

$$
A R_{i, t}=R_{i, t}-E\left[R_{i, t}\right]
$$

Where: $A R_{i, t}=$ abnormal return of the i security in the $\mathrm{t}-$ period; $R_{i, t}=$ Realized return that occurs for the i security in the t- period; $E\left[R_{i, t}\right]=$ Expected return of the i security for $t$ period.

\section{RESULTS AND DISCUSSION}

Abnormal return after the arrival of vaccine raw materials for phase III clinical trials on $19^{\text {th }}$ July, 2020:

Table 1 - Hypothesis Test Results 1

\begin{tabular}{lll}
\hline One Sample Statistic & Mean & 0,055335 \\
& Std. Deviation & 0,128142 \\
& Std. Error Mean & 0,023395 \\
$\mathrm{t}$ & & 2,365 \\
Df & & 29 \\
sig. (2-tailed) & 0,025 \\
\hline
\end{tabular}

Source: Secondary Data, 2021.

Table 1 shows a mean value of 0.055335 and a positive t-value of 2.365 at 0 to 10 days after the event in a state-owned pharmaceutical company. These results prove that there is a positive abnormal return after the arrival of vaccine raw materials for phase III clinical trials. sig value. (2-tailed) shows $0.025<0.05$, which means that there is a significant positive abnormal return after the arrival of vaccine raw materials for the purposes of stage III testing.

This result states that hypothesis 1 is accepted. Shares of state-owned pharmaceutical companies reacted positively to the arrival of vaccine raw materials for phase III clinical trials. This result is in line with the research of Welley et al (2020) namely the stock price of KAEF before the announcement of vaccine development and the stock price of KAEF after the announcement of vaccine development there is a significant difference and INAF's stock price before the announcement of vaccine development and INAF's stock price after the announcement of vaccine development there is a significant difference. This result also proves that investors perceive this information as a strong signal so that the market reacts immediately to state-owned pharmaceutical companies. 
Abnormal return after phase III vaccine clinical trial on $11^{\text {th }}$ August, 2020:

Table 2 - Hypothesis Test Results 2

\begin{tabular}{lll}
\hline One Sample Statistic & Mean & $-0,009301$ \\
& Std. Deviation & 0,023731 \\
$\mathrm{t}$ & Std. Error Mean & 0,004333 \\
Df & & $-2,147$ \\
sig. (2-tailed) & & 29 \\
\hline
\end{tabular}

Source: Secondary Data, 2021.

Table 2 shows a mean value of -0.09301 and a negative t-value of -2.147 at 0 to 10 days after the event. These results indicate that on average there is a negative abnormal return after the Phase III clinical trial. sig value. (2-tailed) each showed $0.040<0.05$ at 0 to 10 days after the event which meant there was a significant negative abnormal return after the event of the Phase III vaccine clinical trial.

This result states that hypothesis 2 is rejected. Shares of state-owned pharmaceutical companies did not react positively to the Phase III vaccine clinical trial. (Vierlboeck and Nilchiani, 2021) found for all companies, the correlation after vaccine distribution started was negligible or very negative, indicating a potentially different type of popularity based on side effects or distribution problems. From the results of this study, the rejection of hypothesis 2 is possible because investors have reacted since the arrival of the raw materials for the purposes of phase III clinical trials and the market has reacted strongly enough to the event of hypothesis 1 so that it no longer responds positively after clinical trials are carried out due to the proximity of events.

Abnormal return on arrival of phase 1 vaccine on $6^{\text {th }}$ December, 2020:

Table 3 - Hypothesis Test Results 3

\begin{tabular}{lll}
\hline One Sample Statistic & Mean & 0,010678 \\
& Std. Deviation & 0,086619 \\
$\mathrm{t}$ & Std. Error Mean & 0,016085 \\
Df & & 0,664 \\
sig. (2-tailed) & & 28 \\
\hline
\end{tabular}

Source: Secondary Data, 2021.

Table 3 shows a mean value of 0.010678 and a positive t-value of 0.664 at 0 to 10 days after the event. These results prove that there is a positive abnormal return after the event. Although it gives a positive abnormal return, it is not statistically significant which is described by the value of sig. (2-tailed) shows $0.512>0.05$, which means that there is no significant positive abnormal return after the arrival of stage 1 vaccine in Indonesia.

This result states that hypothesis 3 is rejected. Shares of state-owned pharmaceutical companies did not react significantly to the arrival of phase 1 vaccine in Indonesia. Vaccines would provide increased protection against the severity and even death of COVID-19 (Pandey and Parajuli, 2021). Burdekin and Harrison (2021) find a relationship not only globally but also by individual continent each month between March and December 2020, a range between the extreme pessimism seen in market reactions early in the pandemic to greater optimism emerging later, driven by news exciting vaccines in November and December 2020. Vaccine news is certainly encouraging for all parties. However, the findings were different in this study. The hope that this pandemic will end quickly is getting closer and closer to reality. Investors do not respond to the event of the arrival of the vaccine which is described in the absence of significant abnormal returns after the event. This is possible because the vaccines will be given free of charge to all Indonesians so that they do not have a significant financial impact on state-owned pharmaceutical issuers. 
Abnormal return after administering the first vaccine in Indonesia on January 13, 2021:

Table 4 - Hypothesis Test Results 4

\begin{tabular}{lll}
\hline One Sample Statistic & Mean & $-0,053227$ \\
& Std. Deviation & 0,021015 \\
$\mathrm{t}$ & Std. Error Mean & 0,003837 \\
Df & & $-13,873$ \\
sig. (2-tailed) & & 29 \\
\hline
\end{tabular}

Source: Secondary Data, 2021.

Table 4 shows a mean value of -0.053227 and a negative t-value of -13.873 at 0 to 10 days after the event. These results indicate that there is a negative abnormal return after the vaccination program started for all Indonesian people. sig value. (2-tailed) shows $0.000<0.05$ at 0 to 10 days after the event which means there is a significant negative abnormal return after the first vaccine administration event in Indonesia.

This result states that hypothesis 4 is rejected. Shares of state-owned pharmaceutical companies reacted negatively to the administration of the first vaccine in Indonesia. Vaccines play an important role in improving global public health, with the ability to stem the spread of infectious diseases and the potential to eradicate them altogether (Xue and Oulette). If the pandemic can finally be ended, the vaccine will play a very important role. The new pandemic will end if there is herd immunity, the condition is that $70 \%$ of the group has immunity to the virus. With the vaccine is expected to accelerate the achievement of herd immunity. However, this is not yet strong enough to give a signal to investors. The results of the study by Zhang et al (2020) found that two doses of CoronaVac at different concentrations and using different dosing schedules were well tolerated and moderately immunogenic in healthy adults aged 18-59 years. All positive news related to vaccines coupled with the injection of the first COVID-19 vaccine in Indonesia has not become a positive signal for state-owned pharmaceutical companies. This result was also due to the fact that the market had reacted earlier to the news that the vaccination program would be implemented, so that after the vaccination program started, investors tended to react first. This is evidenced by the stock prices of state-owned pharmaceutical companies experiencing positive returns before the date of the vaccination program.

\section{CONCLUSION}

There is a positive market reaction for state-owned pharmaceutical companies to the arrival of vaccine raw materials for phase II clinical trials on July 19, 2020. Investors responded positively to the arrival of vaccine raw materials as predicted. The public hopes that with the discovery of a COVID-19 vaccine, it will gradually be able to stop the ongoing pandemic. Moreover, state-owned pharmaceutical companies, namely Kimia Farma and Indofarma, will be appointed to manufacture and distribute vaccines. The positive news directly leads to the issuer concerned so that investors quickly respond.

There is no positive market reaction in state-owned pharmaceutical companies to the phase III vaccine clinical trial event on August 11, 2020. The market did not respond to the vaccine clinical trial event, possibly because investors had responded significantly to previous events. The distance of events that are too close is the cause of the lack of investor response to this event.

There was no significant market reaction in state-owned pharmaceutical companies after the arrival of the phase 1 vaccine in Indonesia on December 6, 2020. The arrival of the vaccine from Sinovac, China for the first time was not responded to by investors, although this event strengthened hopes that the COVID-19 pandemic would end soon. The overwhelming positive response to the previous arrival of vaccine raw materials made investors less responsive to subsequent events. In addition, it is planned that the vaccination will be injected free of charge so that it will not have a significant impact on the company's finances. 
There is no positive market reaction in state-owned pharmaceutical companies to the administration of the first vaccine in Indonesia on January 13, 2021. This event is considered by investors not to be a strong positive signal even though the first vaccine injection was also directly given to President Jokowi. In addition, the stock prices of state-owned companies have moved before the vaccination program started, which means investors have responded before the event date.

\section{REFERENCES}

1. Agustiawan, K. E., Sujana, E. 2020. Reaksi Pasar Modal Indonesia Sebelum and Sesudah Pengumuman Kebijakan Pemerintah Tentang Status Darurat Bencana COVID19. Jurnal Akuntansi Profesi Vol. 11 NO.2 DESEMBER 2020 p-ISSN:2338-6177 e-ISSN : 2686-2468.

2. Burdekin, R.C.K \& Harrison, S. 2021. Relative Stock Market Performance during the Coronavirus Pandemi: Virus vs. Policy Effects in 80 Countries. Journal of Risk and Financial Management 2021, 14, 177.

3. Chowdbury, E. K., Khan, I. I., Dhar, B. K. 2020. Catastrophic Impact of COVID-19 on the Global Stock Markets and Economic Activities. Journal of the W. Michael Hoffman Center for Business Ethics at Bentley University DOI: 10.1111/basr.12219.

4. Danzon, P. M. \& Pereira, N. S. 2011. Vaccine Supply: Effects of Regulation and Competition. Int. J. of the Economics of Business, Vol. 18, No. 2, July 2011, pp. 239-271 DOI: $10.1080 / 13571516.2011 .584429$.

5. Demirci, E. Z., 2020. Erkip, N. K. 2020. Designing Intervention Scheme for Vaccine Market: A Bilevel Programming Approach. Flexible Services and Manufacturing Journal (2020) 32:453-485 https://doi.org/10.1007/s10696-019-09348-5.

6. Gadelha, C. A. G., Braga, P. S. D. A., Montenegro, K. B. M. \& Cesário, B. B. 2020. Access to Vaccines in Brazil and The Global Dynamics of The Health EconomicIndustrial Complex. Cad. Saúde Pública 2020; 36 Sup 2:e00154519 DOI: 10.1590/0102$311 \times 00154519$.

7. Guo, F., Cao, E. 2020. Does Reference Dependence Impact Intervention Mechanisms in Vaccine Markets? Sustainability 2020, 12, 6371; doi:10.3390/su12166371.

8. Halim, M. 2021. A Report on COVID-19 Variants, COVID-19 Vaccines and the Impact of the Variants on the Efficacy of the Vaccines. Journal of Clinical and Medical Research ISSN: 2582-4333 DOI: https://doi.org/10.37191/Mapsci-2582-4333-3(3)-066.

9. Hartono. 2021. Covid-19 Vaccine: Global Stock Market "Game Changer". Journal of Asian Multicultural Research for Economy and Management Study ISSN: 2708-9711 Vol. 2 No. 2, 2021 (page 008-017).

10. Hartono, Jogiyanto. 2009. Metode Penelitian Kuantitatif, Kualitatif, and R\&D. Alfabeta.

11. Hartono, Jogiyanto. 2010. Metode Penelitian Bisnis. Bandung: CV Alfabeta.

12. Ling, H. W. 2020. World Vaccines and Immunology Market Analysis. Journal of Vaccine \& Vaccination ISSN: 2167-7560.

13. Masnun, M. A., Sulistyowati, E., Ronaboyd, I. 2021. Perlindungan Hukum Atas Vaksin COVID-19 and Tanggung Jawab Negara Pemenuhan Vaksin Dalam Mewujudkan Negara Kesejahteraan. DiH: Jurnal Ilmu Hukum Volume 17 Nomor 1 Februari 2021.

14. Muhyiddin. 2020. Covid-19, New Normal and Perencanaan Pembangunan di Indonesia. The Indonesian Journal of Development Planning. Volume IV No. 2 - Juni 2020.

15. Pandey, A., Parajuti, A., Belbase, P. 2020. COVID-19 Vaccine Development to Vaccination. J Nepal Health Res Counc 2020 Oct-Dec;18(49): 807-9.

16. Polack, F. P., Thomas, S. J., Kitchin, N., Absalon, J., Gurtman, A., Lockhart, S., Perez, L., Marc, G. P., Moreira, E. D., Zerbini, C., Bailey, R., Swanson, K. A., Roychoudhury, S., Koury, K., Li, P., Kalina, W. V., Cooper, D., Frenck, R. W., Hammitt, L. L., Türeci, O., Nell, H., Schaefer, A., Ünal, S., Tresnan, D. B., Mather, S., Dormitzer, P. R., Şahin, U., Jansen, K. U. \& Gruber, W. C. 2020. Safety and Efficacy of the BNT162b2 mRNA Covid19 Vaccine. The New England Journal of Medicine December 31, 2020 vol. 383 no. 27.

17. Prado, E. O., Espin, E, Vásconez, J., Burneo, N. R., Kyriakidis, N. C. \& Cortés, A. L. 
Vaccine Market and Production Capabilities in The Americas. Tropical Diseases, Travel Medicine and Vaccines https://doi.org/10.1186/s40794-021-00135-5.

18. Radice, A., Carli, G., Macchia, D., Farsi, A. 2019. Allergic Reactions after Vaccination: Translating Guidelines into Clinical Practice. Eur Ann Allergy Clin Immunol Vol 51, N 2, 51-61, 2019 DOI 10.23822/EurAnnACI.1764-1489.86.

19. Rossman, H., Shilo, S., Meir, T., Gorfine, M., Shalit, U. \& Segal, E. 2021. COVID-19 Dynamics After A Nationa Immunization Program In Israel. Nature Medicine VOL 27 June $2021 \mathrm{Hal} .1055-1061 \mathrm{https}: / /$ doi.org/10.1038/s41591-021-01337-2.

20. Sambuari, I. B., Saerang, I. S., Maramis, J. B. 2020. Reaksi Pasar Modal Terhadap Peristiwa Virus Corona (COVID-19) Pada Perusahaan Makanan and Minuman yang Terdaftar di Bursa Efek Indonesia. Jurnal Ilmiah Manajemen Bisnis and Inovasi Universitas Sam Ratulangi Vol.7 No.3 September 2020, Hal. 407-415.

21. Saraswati, Henny. 2020. Dampak Pandemi Covid-19 Terhadap Pasar Saham Di Indonesia. JAD: Jurnal Riset Akuntansi and Keuangan Dewantara Vol. 3 No. 2, Juli (2020) - Desember (2020) Halaman 153 sampai 163.

22. Vierlboeck, M. \& Nilchiani, R. R., Effects of COVID-19 Vaccine Developments and Rollout on the Capital Market - A Case Study. School of Systems \& Entreprises, Stevens Institute of Technology, Hoboken, New Jersey, USA.

23. Welley, M. M., Oroh, F. N. S., Walangitan, M. D. B. 2020. Perbandingan Harga Saham Perusahaan Farmasi BUMN Sebelum and Sesudah Pengembangan Vaksin Virus Corona (COVID-19). Jurnal IImiah Manajemen Bisnis and Inovasi Universitas Sam Ratulangi Vol.7 No.3 September 2020, Hal. 571-579 ISSN 2356-3966 E-ISSN: 26212331.

24. Xue, Q. C., \& Ouellette, L. L. 2020. Innovation policy and the market for vaccines. Journal of Law and the Biosciences, 1-41.

25. Yanti, N. P. E. D., Nugraha, I. M. A. D. P., Wisnawa, G. A., Agustina, N. P. D., Diantari, N. P. A. 2020. Gambaran Pengetahuan Masyarakat tentang COVID-19 and Perilaku Masyarakat di Masa Pandemi COVID-19. Jurnal Keperawatan Jiwa FIKKes Universitas Muhammadiyah Semarang bekerjasama dengan PPNI Jawa Tengah Volume 8 No 3, 2020, Hal 491 - 504.

26. Zhang, Y., Zeng, G., Pan, H., Li, C., Hu, Y., Chu, K., Han, W., Chen, Z., Tang, R., Yin, W., Chen, X., Hu, Y., Liu, X., Jiang, C., Li, N., Yang, M., Song, Y., Wang, X., Gaot, Q. \& Zhut, F. Safety, Tolerability, and Immunogenicity of An Inactivated SARS-CoV-2 Vaccine in Healthy Adults Aged 18-59 Years: A Randomised, Double-Blind, Placebo-Controlled, Phase 1/2 Clinical Trial. www.thelancet.com/infection Vol. 21 February 2021. 